\title{
College English Culture Teaching from the Perspective of Globalization
}

\author{
Qifeng Meng \\ Jilin Agricultural University, Changchun 130118, China
}

\begin{abstract}
English is not only a communication tool of language, but also a means of cultural dissemination. At present, there is a widespread misunderstanding of "only-tool theory" in College English teaching practice, which is not conducive to the cultivation of compound talents and the improvement of its quality. In this paper, in view of the relationship between diversification and diversity of culture and language and culture in the perspective of globalization, specifically explains the theoretical basis of College English culture teaching in the perspective of globalization. From the College English teaching culture flaw phenomenon to analyze, combined with the College English teaching culture flaw phenomenon, put forward the following four implementation approaches on College English culture teaching: establish appropriate culture teaching concept, ensure multicultural teaching objectives, adopt rich culture teaching strategies, and form scientific teaching evaluation system of culture.
\end{abstract}

Keywords: College English; Culture teaching; Globalization.

\section{Introduction}

The tide of economic globalization, cultural diversity, and education internationalization and so on, promotes the integration of the subjects, the integration of talents, and the integration of training. English, as the "universal language", is not only a kind of language skill and communication tool, but also the carrier of social thought and the means of cultural dissemination. However, College English "only-tool theory" phenomenon exists widely in our country, and both teachers and students have a lot of misunderstandings. At present, the defects of the evaluation system of College English test result in that some teachers ignore the cultivation of cultural input and the ability of cross-cultural communication [1]. Additionally, misreading of the guiding thought of "pay attention to the cultivation of students' English language knowledge and application skills, learning strategies and cross-cultural communicative competence" in College English Curriculum Requirements. It results in that some teachers only pay attention to the introduction of European and American culture, while almost ignore the culture diversity and global. These errors have a wide influence on the teaching and learning of College English culture.

\section{Lack of "Culture" in College English Teaching from the Perspective of Globalization}

\subsection{Weak Cultural Awareness of College English Teaching Main Body}

In this paper, through the use of the questionnaire survey, investigate the culture teaching and the current situation of cultural awareness on the students of a University. The investigation objects are the freshmen and sophomore students in a University, whose professionals cover legal, business management, computer application management, civil engineering, logistics management and other non-English majors [2]. Questionnaires were distributed with a total number of 150, 150 valid questionnaires, and effective recovery rate was $100 \%$. From the recovered samples, it is seen that they are quite representative, available for reference, as shown in Table 1, Table 2, Table 3, and Table 4.

Table 1 Percentage of College students being investigated

\begin{tabular}{|c|c|c|}
\hline Categories & The number of students & Percentage \\
\hline Freshmen & 60 & $40 \%$ \\
\hline Sophomore & 90 & $60 \%$ \\
\hline The total & 150 & $100 \%$ \\
\hline
\end{tabular}


Table 2 Sampling number of students in different professional

\begin{tabular}{|c|c|c|c|c|c|c|}
\hline & Law & $\begin{array}{c}\text { Business } \\
\text { management }\end{array}$ & $\begin{array}{c}\text { Computer } \\
\text { application } \\
\text { management }\end{array}$ & $\begin{array}{c}\text { Civil } \\
\text { engineering }\end{array}$ & $\begin{array}{c}\text { Logistics } \\
\text { management }\end{array}$ & $\begin{array}{c}\text { The total } \\
\text { number of } \\
\text { students }\end{array}$ \\
\hline Freshmen & & & 30 & 30 & & 60 \\
\hline Sophomore & 30 & 30 & & & 30 & 90 \\
\hline The total & & & & & & 150 \\
\hline
\end{tabular}

Table 3 Classification of the content of cultural test

\begin{tabular}{|c|c|c|c|c|c|c|}
\hline Classification & $\begin{array}{c}\text { Self-cultural } \\
\text { knowledge }\end{array}$ & $\begin{array}{c}\text { Festival } \\
\text { Culture }\end{array}$ & $\begin{array}{c}\text { Social culture (greetings, } \\
\text { introductions, time, praise, } \\
\text { farewell, apology, etc.) }\end{array}$ & $\begin{array}{c}\text { Content of } \\
\text { culture } \\
\text { teaching } \\
\text { materials }\end{array}$ & $\begin{array}{c}\text { Culture } \\
\text { teaching } \\
\text { and method }\end{array}$ & $\begin{array}{c}\text { The } \\
\text { total }\end{array}$ \\
\hline $\begin{array}{c}\text { Volume } \\
\text { percentage (\%) }\end{array}$ & 6 & 1 & 16 & 1 & 6 & 30 \\
\hline
\end{tabular}

Table 4 Order on the problems of College English teachers by College students

\begin{tabular}{|c|c|c|c|c|}
\hline & \multicolumn{2}{|l|}{$\begin{array}{c}\text { It is believed that the teacher introduced the } \\
\text { rich Chinese culture knowledge in English } \\
\text { teaching. }\end{array}$} & $\begin{array}{c}\text { It is believed that the teaching of western culture } \\
\text { can meet the needs of students in English classroom } \\
\text { teaching. }\end{array}$ \\
\hline $\begin{array}{c}\text { A Very } \\
\text { agree }\end{array}$ & 0 & 0 & 6 & 4 \\
\hline B Agree & 11 & 7.33 & 49 & 32.67 \\
\hline C Disagree & 117 & 78 & 72 & 48 \\
\hline $\begin{array}{c}\text { D Very } \\
\text { disagree }\end{array}$ & 22 & 14.67 & 18 & 12 \\
\hline E Unsure & 0 & 0 & 5 & 3.33 \\
\hline $\begin{array}{c}\text { Not } \\
\text { selected }\end{array}$ & 0 & 0 & 0 & 0 \\
\hline The number of students & Percentage (\%) & Percentage (\%) \\
\hline
\end{tabular}

The recovered sample survey result shows that the average score of freshman students is 65.78, and the average score of sophomore students is 66.64 . The highest score of freshman is 72 points, the highest score of sophomore students is 74. From the overall level, students' cultural awareness is weak.

From the survey results in Table 4, it can be seen that more than $92 \%$ of the students believed that College English teachers have not introduced Chinese culture in the classroom teaching, and more than $60 \%$ of the students think that teachers' teaching cannot meet their understanding of the knowledge of western culture in the teaching of College English. It is seen that English teachers also lack cultural awareness in teaching.

\subsection{Restrictions of Traditional College English Teaching Strategies in the Development of Culture Teaching}

(1) Current Situation of College English Teaching Strategies

At present, some Colleges and universities, due to the influence of traditional English teaching ideas, still adopt the method of taking class as unit, follow the classroom teaching mode of "review the old lesson - introduction of new lesson - explain the new lesson - consolidate the new lesson arrange assignments". The classroom teaching mode taking teachers as the main body is based on language, only paying attention to the teaching of language structure and other knowledge. Therefore, in support of this concept, College English teachers mostly adopt the method of explaining vocabulary and grammar, analyzing grammar structure, and mutually translate in Chinese and English [3]. The implementation of this teaching mode, on the one hand is to facilitate the organization and supervision of the teaching content, teaching activities and teaching process; on the other hand, also promotes students to master more comprehensive knowledge of the language in a relatively short time. 
(2) An Analysis of the Restrictions of Current College English Teaching Strategies in the Development of Culture Teaching

With the development of society and the continuous reform of education, the traditional teaching mode and method have some disadvantages. From the point of view of College English classroom teaching mode, the teacher is the subject of classroom teaching. They implement a unified requirement on teaching materials, ignoring the cultural personality of the students from different cultural backgrounds. From the point of view of College English teaching method, in the perspective of teachers, the grammar translation method is a teaching method. In the perspective of students, the grammar translation method is an accepted method. In the teaching process, this method only emphasizes the instilling of language knowledge and the input of the English language, but ignore the output of the English language. Traditional College English teaching mode and method are not only not conducive to the cultivation and development of students' creative thinking, but also averse to the cultivation and development of critical thinking ability.

\subsection{Lack of Culture in College English Teaching Evaluation System from the Perspective of Globalization}

(1) The evaluation form is too simplistic. The traditional teaching evaluation system only emphasizes on the end evaluation of students' test scores, but ignores the formative evaluation of students in the learning process.

(2) The evaluation subject is too limited. Subjects participating in evaluation can only be teachers or relevant teaching and administrative staffs. Students are only regarded as the evaluation object who are unable to participate in it.

(3) The evaluation content is too intellectual. Many Colleges and universities evaluate the effect of learning according to students' understanding of English knowledge and master, without tracking the changes of learning methods, student's attitude in students' learning process, neglecting the students' practical using ability of language and culture [4].

\section{Implementation Paths of College English Culture Teaching from the Perspective of Globalization}

\subsection{Establish Correct Concept of College English Culture Teaching}

(1) Require teachers to organically combine language and culture in English teaching practice. College English teachers should pay attention to explain cultural content in imparting knowledge to students, in which they can appropriately add suitable cultural education.

(2) Ask teachers to pay attention to the synchronous input of the western culture and the native culture. In College English culture teaching, in the explanation of the western culture, and at the same time, attach importance to the emphasis on the native culture. Through synchronous input of western culture and the native culture, let students know the differences in the comparison and learning of the two kinds of culture, and acquire social communication necessary cross cultural communication consciousness and skills in appreciation of the two cultures.

(3) Demand teachers to establish correct values of cross culture teaching. In the meanwhile, teachers taking English as a carrier of culture teaching, they should guide students to recognize the cultural difference between English culture and Chinese culture with a tolerant attitude, and respect the cultural differences. Teachers should guide students to correctly know and deeply understand the advanced culture contained in the English language, but also prevent students from wrongly identifying or blindly worshiping the backward culture hidden behind the English language.

\subsection{Establish the Multiple College English Culture Teaching Objectives}

Under the background of economic activities globalization, the flow of talents has been quietly occurred in the world. Multicultural literacy including the global consciousness, requires the students can not only absorb the essence and discard the dross of foreign culture, but also have a comparatively profound understanding of the native culture, and maintain the specialty of viewing 
and handling problems [5]. Colleges and universities should, according to the overall requirements in the Teaching Requirements, formulate a scientific, systematic and individualized College English teaching syllabus, guide the College English teaching in the school. Schools have conditions, for different specialties of the school, can establish teaching objective in accordance with the professional employment field, fully embody the professional characteristics, and reveal the personalized features. This teaching objective is more targeted, lay the foundation for achieving the best teaching results, and better service the society.

\subsection{Adopt Rich Cultural Teaching Strategies of College English}

First of all, teachers should use the rich cultural teaching strategies to carry out the cultural introduction before text teaching. Firstly, adopt audio-visual import method, such as the form of seeing a movie. The second is the use of heuristic teaching method. Before the text teaching, lead to the topic of the article through the way of teachers asking questions, thereby stimulating the enthusiasm of students to participate in. The third one is the introduction of cultural background knowledge.

Secondly, teachers should use the rich cultural teaching strategies to carry on the cultural experience in the text teaching. One is the communicative approach, that is, after leading to the topic of the article through the way of teachers asking questions, let students actively participate in the discussion of the topic of the article. The second one is the semantic mining method. Due to the impact of cultural factors, the meaning of many words in English and Chinese has diversity that the same word in different cultural environment may have a completely different meaning [6]. The third one is the comparative teaching method. This is the often used culture teaching methods in university English teaching. The fourth one is the integration of teaching method, namely the teaching methods, in the process of teaching, organically combine cultural content with language materials.

Table 5 Process evaluation of reading teaching

\begin{tabular}{|c|c|c|c|c|c|c|}
\hline Items of evaluation & Contents of evaluation & \multicolumn{5}{|c|}{ Levels of evaluation } \\
\hline $\begin{array}{l}\text { Complete the reading } \\
\text { task }\end{array}$ & $\begin{array}{l}\text { Have a strong understanding } \\
\text { ability and grasp the main idea } \\
\text { and details }\end{array}$ & Outstanding & Excellent & Good & Improved & Common \\
\hline $\begin{array}{l}\text { Note reading notes / } \\
\text { feelings }\end{array}$ & $\begin{array}{l}\text { Recite the relevant words and } \\
\text { classic sorting, write reaction to } \\
\text { a book or an article }\end{array}$ & & & & & \\
\hline $\begin{array}{l}\text { Reading plan and } \\
\text { monitoring }\end{array}$ & $\begin{array}{l}\text { Develop effective reading plan } \\
\text { according to the individual } \\
\text { situation, and determine clear } \\
\text { objectives }\end{array}$ & & & & & \\
\hline $\begin{array}{c}\text { Extracurricular } \\
\text { background } \\
\text { knowledge reading }\end{array}$ & $\begin{array}{c}\text { Learn to choose extra-curricular } \\
\text { reading materials, reading } 1000 \\
\text { words per week }\end{array}$ & & & & & \\
\hline $\begin{array}{l}\text { Reading method } \\
\text { usage }\end{array}$ & $\begin{array}{l}\text { Reflect on the gains and losses, } \\
\text { optimize the learning strategy, } \\
\text { and evaluate the learning effect }\end{array}$ & & & & & \\
\hline $\begin{array}{l}\text { Participation in group } \\
\text { activities }\end{array}$ & $\begin{array}{l}\text { Actively participate in reading } \\
\text { activities, and friendly cooperate } \\
\text { with people, and share the results }\end{array}$ & & & & & \\
\hline Usual test & $\begin{array}{r}\text { Percentile } \\
\text { divided into } \\
85-100 \text { five } \mathrm{gr}\end{array}$ & $\begin{array}{l}\text { scoring systen } \\
-59,60-64,65 \\
\text { des }(150 \text { poin }\end{array}$ & $\begin{array}{l}\text { can be } \\
74,75-84, \\
\text { and so on) }\end{array}$ & & & \\
\hline $\begin{array}{l}\text { Attitude towards } \\
\text { evaluation }\end{array}$ & $\begin{array}{l}\text { Is it serious, objective and fair } \\
\text { when evaluate themselves and } \\
\text { others }\end{array}$ & & & & & \\
\hline $\begin{array}{c}\text { Comprehensive } \\
\text { evaluation }\end{array}$ & & & & & & \\
\hline Leader signature & Teacher signa & Signa & ure of the pe & rson be & ng evaluatec & \\
\hline
\end{tabular}


Finally, after the end of the text teaching, teachers and students have to carry out cultural withdrawal. That is to say, they should return to their own country and the local culture. Multicultural teaching in the perspective of globalization not only emphasizes how teachers let students carry out cultural import and cultural experience, but the cultural withdraw is a good form of realizing multicultural teaching.

\subsection{Form a Scientific Evaluation System for College English Teaching}

The evaluation system of College English culture teaching in the perspective of globalization should reflect the evaluation subject of the diversification and the form of variety, and col-ligate the combination of "formative assessment" and "final evaluation". Specifically speaking, mutual evaluation among students can be used for reading evaluation [7]. Taking the group as the unit, by group exchanges of the contents of the article, fill in the evaluation forms (see in Table 5). All members are assessment person and the evaluated person.

\section{Conclusion}

The formation of multi culture driven by globalization is an important feature of today's society. English, as a universal language, is not only a language communication tool, but also a means of cultural dissemination. In view of the widely-existed phenomenon of "only tool theory" in College English teaching, this paper makes a research on the cultural teaching of College English in the perspective of globalization. The present situation of cultural loss in College English culture teaching is discussed, and the implementation paths of College English culture teaching is explored according to the understanding of culture teaching.

\section{References}

[1] Borg S, Liu Y D. Chinese college English teachers' research engagement [J]. TESOL Quarterly, 2013, 47(2): 270-299.

[2] Bao W. Research on college English teaching based on intercultural communication in engineering universities [J]. World Transactions on Engineering and Technology Education, 2014, 12(3): 191-195.

[3] Hong J I N. On the Significance of Chinese Culture in English Teaching [J]. Curriculum, Teaching Material and Method, 2013, 8: 014.

[4] Li J. A Study on Ecological College English Teaching [J]. International Journal for Innovation Education and Research, 2016, 2(12).

[5] Dan L. Research on English Teaching Reform of Sino-foreign Joint Program from the Way of Culture-A Case Study of Xuchang College [J]. Journal of Shangqiu Vocational and Technical College, 2013, 1: 041.

[6] Critical perspectives on language teaching materials [M]. Springer, 2013.

[7] Appleman D. Critical encounters in secondary English: Teaching literacy theory to adolescents [M]. Teachers College Press, 2014. 